Article

\title{
Synthesis, Molecular and Supramolecular Structures of New Cd(II) Pincer-Type Complexes with s-Triazine Core Ligand
}

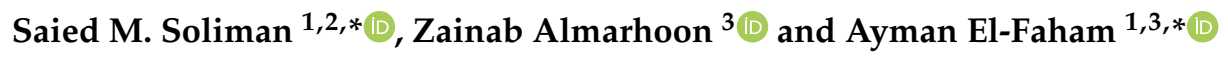 \\ 1 Department of Chemistry, Faculty of Science, Alexandria University, P.O. Box 426, Ibrahimia, \\ Alexandria 21321, Egypt \\ 2 Department of Chemistry, Rabigh College of Science and Art, King Abdulaziz University, P.O. Box 344, \\ Rabigh 21911, Saudi Arabia \\ 3 Department of Chemistry, College of Science, King Saud University, P. O. Box 2455, Riyadh 11451, \\ Saudi Arabia; zalmarhoon@ksu.edu.sa \\ * Correspondence: saied1soliman@yahoo.com (S.M.S.); aymanel_faham@hotmail.com (A.E.-F.)
}

Received: 5 April 2019; Accepted: 24 April 2019; Published: 27 April 2019

\begin{abstract}
The manuscript described the synthesis and characterization of the new $\left[\mathrm{Cd}(\mathrm{BDMPT})_{2}\right]\left(\mathrm{ClO}_{4}\right)_{2} ; 1$ and $\left[\mathrm{Cd}_{2}(\mathrm{MBPT})_{2}\left(\mathrm{H}_{2} \mathrm{O}\right)_{2} \mathrm{Cl}\right]\left(\mathrm{ClO}_{4}\right)_{3} \cdot 4 \mathrm{H}_{2} \mathrm{O} ; 2$ s-triazine pincer-type complexes, where BDMPT and MBPT are 2,4-bis(3,5-dimethyl-1H-pyrazol-1-yl)-6-methoxy-1,3,5triazine and 2-methoxy-4,6-bis(2-(pyridin-2-ylmsethylene)hydrazinyl)-1,3,5-triazine respectively. The synthesized complexes were characterized using Fourier-transform infrared spectroscopy (FTIR), ${ }^{1} \mathrm{H}$ and ${ }^{13} \mathrm{C}$ NMR spectroscopy, and the single-crystal $\mathrm{X}$-ray diffraction technique. The homoleptic mononuclear complex (1) contains a hexa-coordinated $\mathrm{Cd}$ (II) center with two tridentate $N$-pincer ligand (BDMPT) with a highly distorted octahedral coordination environment located as an intermediate case between the octahedron and trigonal prism. The heteroleptic dinuclear complex (2) contains two hepta-coordinated Cd(II) coordination spheres where each Cd(II) is coordinated with one pentadentate pincer $N$-chelate (MBPT), one water, and one bridged chloride ligand connecting the two metal ions. The different intermolecular interactions in the studied complexes were quantified using Hirshfeld analysis. Their thermal stabilities and FTIR spectra were compared with the corresponding free ligands. The strength and nature of $\mathrm{Cd}-\mathrm{N}, \mathrm{Cd}-\mathrm{O}$, and $\mathrm{Cd}-\mathrm{Cl}$ coordination interactions were discussed in light of atoms in molecules calculations (AIM). The M(II)-BDMPT and M(II)-MBPT interaction energies revealed that such sterically hindered ligands have higher affinity toward large-size metal ions $(\mathrm{M}=\mathrm{Cd})$ compared to smaller ones $(\mathrm{M}=\mathrm{Ni}$ or $\mathrm{Mn})$.
\end{abstract}

Keywords: cadmium(II); hexa- and hepta-coordinated; AIM; Hirshfeld; pincer ligand

\section{Introduction}

The self-assembly technique is the most simple and direct way used in inorganic chemistry to construct supramolecular extended metal organic frameworks [1-3], in which the molecular units are held together by strong metal-ligand interactions or weaker non-covalent interactions [4-10]. In this context, 1,3,5-triazine (s-triazine) derivatives are attractive building blocks to construct metal complexes due to their versatile coordination modes [11-16] and excellent ability to form coordination compounds with interesting extended supramolecular architectures [17-19].

Coordination compounds of $\mathrm{Cd}$ (II) attracted much interest due to their fluorescence properties where $\mathrm{Cd}$ (II) has the ability to change the emission characteristics of ligand to which it is coordinated [20]. Hence, Cd(II) complexes have interesting photochemical and photophysical properties [21-23]. In addition, $\mathrm{Cd}(\mathrm{II})$ complexes of organic ligands rich in nitrogen are important energetic materials [24]. 
In general, energetic metal-organic compounds [25-27] attracted a lot of interest because of their exciting structures, and good properties of explosion [28-35]. From a structural point of view, $\mathrm{Cd}(\mathrm{II})$ has a great ability to react with $\mathrm{N}$-donor ligands leading to coordination compounds displaying versatile coordination numbers (4-8) and geometries. Selecting appropriate organic ligands is a critical step and the most valid strategy to build such interesting coordination compounds [36,37]. In this work, two new $\mathrm{Cd}$ (II) complexes of $s$-triazine-based ligands having different denticity (Figure 1) were synthesized and characterized by spectroscopic techniques. Their molecular and supramolecular structures were explored using single-crystal X-ray structure combined with Hirshfeld analysis of molecular packing. In addition, their thermal stabilities were discussed compared to the corresponding free ligands. Atoms in molecules calculations were used to assign the nature and strength of the $\mathrm{Cd}-\mathrm{N}$, $\mathrm{Cd}-\mathrm{O}$, and $\mathrm{Cd}-\mathrm{Cl}$ coordination interactions.<smiles>COc1nc(-n2nc(C)cc2C)nc(-n2nc(C)cc2C)n1</smiles>

BDMPT<smiles>CCCCCCOc1nc(N/N=C/c2ccccn2)nc(N/N=C/c2ccccn2)n1</smiles>

MBPT

Figure 1. Structure of the $s$-triazine-based ligands, 2,4-bis(3,5-dimethyl-1H-pyrazol-1-yl)-6-methoxy1,3,5-triazine (BDMPT) and 2-methoxy-4,6-bis(2-(pyridin-2-ylmsethylene)hydrazinyl)-1,3,5-triazine (MBPT).

\section{Experimental}

\subsection{Materials and Methods}

All chemicals were obtained from Sigma-Aldrich (Sigma-Aldrich Chemie GmbH, 82024 Taufkirchen, Germany). Fourier-transform infrared (FTIR) spectra $\left(4000-400 \mathrm{~cm}^{-1}\right)$ were measured on an Alpha Bruker spectrophotometer (Rheinstetten, Germany) in KBr pellets. Nuclear magnetic resonance $\left({ }^{1} \mathrm{H}\right.$ NMR and ${ }^{13} \mathrm{C}$ NMR) spectra were measured on a $400-\mathrm{MHz}$ JEOL (JEOL, Ltd., Tokyo, Japan) spectrometer. Thermogravimetric (TGA) analysis was performed on a TGA Q500 instrument (ELTRA GMbH, Retsch-Allee 1-5, 42781 Haan, Germany). Samples (3-5 mg) were taken in an Al-crucible under dry nitrogen flow $(60 \mathrm{~mL} / \mathrm{min})$ at a heating rate of $7^{\circ} \mathrm{C} / \mathrm{min}$.

\subsection{Syntheses}

\subsubsection{Synthesis of BDMPT and MBPT Ligands}

The ligands BDMPT $[17,18]$ and MBPT $[19]$ were prepared following the method reported by our research group.

\subsubsection{Synthesis of $\left[\mathrm{Cd}(\mathrm{BDMPT})_{2}\right]\left(\mathrm{ClO}_{4}\right)_{2} ; \mathbf{( 1 )}$ and $\left[\mathrm{Cd}_{2}(\mathrm{MBPT})_{2}\left(\mathrm{H}_{2} \mathrm{O}\right)_{2} \mathrm{Cl}\right]\left(\mathrm{ClO}_{4}\right)_{3} \cdot 4 \mathrm{H}_{2} \mathrm{O}$; (2)}

Complexes $\mathbf{1}$ and $\mathbf{2}$ were synthesized by mixing a $5 \mathrm{~mL}$ methanolic solution of the organic ligand $(0.5 \mathrm{mmol})$ with a $5 \mathrm{~mL}$ aqueous solution of $\mathrm{CdCl}_{2}(0.092 \mathrm{~g}, 0.5 \mathrm{mmol})$, followed by addition of $1 \mathrm{~mL}$ of $1: 1$ (v/v, volume/volume) $60 \%$ perchloric acid. The amounts of ligands used for the syntheses of complexes 1 and 2 were $0.150 \mathrm{~g}$ and $0.175 \mathrm{~g}$, respectively. In both cases, the mixture was left to evaporate slowly at room temperature. Complexes $\mathbf{1}$ and $\mathbf{2}$ were formed as colorless crystals after 10 and 15 days, respectively. 
Yield $\mathrm{C}_{28} \mathrm{H}_{34} \mathrm{CdCl}_{2} \mathrm{~N}_{14} \mathrm{O}_{10}$ (1) 83\%. IR ( $\left.\mathrm{KBr}, \mathrm{cm}^{-1}\right)$ : 3162, 3122, 2935, 1619, 1543, 1136, 1106, 1056, 994; (Figure $\mathrm{S} 1$ in the Supplementary Materials). ${ }^{1} \mathrm{H}$ NMR (dimethyl sulfoxide (DMSO)- $d_{6}$ ) $\delta: 2.19$ (s, $\left.6 \mathrm{H}_{b, b^{\prime}}, 2 \mathrm{CH}_{3}\right), 2.65\left(\mathrm{~s}, 6 \mathrm{H}_{a, a^{\prime}}, 2 \mathrm{CH}_{3}\right), 4.03\left(\mathrm{~s}, 3 \mathrm{H}, \mathrm{OCH}_{3}\right), 6.24\left(\mathrm{~s}, 2 \mathrm{H}_{2,2^{\prime}}, \mathrm{CH}\right) \mathrm{ppm}{ }^{13} \mathrm{C}$ NMR (DMSO-d $\left.d_{6}\right)$ : $\delta 13.35\left(C_{b, b^{\prime}}\right), 15.38\left(C_{a, a^{\prime}}\right), 55.58\left(\mathrm{OCH}_{3}\right), 111.79\left(C_{2,2^{\prime}}\right), 144.20\left(C_{3,3^{\prime}}\right), 152.12\left(C_{1,1^{\prime}}\right), 164.08\left(C_{4}\right), 171.91$ $\left(C_{5,5^{\prime}}\right)$ ppm (Figure $\mathrm{S} 2$, Supplementary Materials).

Yield $\mathrm{C}_{32} \mathrm{H}_{42} \mathrm{Cd}_{2} \mathrm{Cl}_{4} \mathrm{~N}_{18} \mathrm{O}_{20}$ (2) 69\%. IR (KBr, cm $\left.{ }^{-1}\right)$ : 3425, 3057, 3010, 2910, 1619, 1586, 1537, 1160 , 1118, 1077 (Figure S1, Supplementary Materials). ${ }^{1} \mathrm{H}$ NMR (DMSO- $\left.d_{6}\right) \delta: 3.97\left(\mathrm{~s}, 3 \mathrm{H}, \mathrm{OCH}_{3}\right), 7.66$ (brs, $\left.2 \mathrm{H}_{b, b^{\prime}}\right), 7.88\left(\mathrm{~d}, 2 \mathrm{H}, 2 \mathrm{H}_{d, d^{\prime}}, J=7.2 \mathrm{~Hz}\right), 8.0\left(\mathrm{t}, 2 \mathrm{H}_{c, c^{\prime}}, J=6.8 \mathrm{~Hz}\right), 8.28\left(\mathrm{~d}, 2 \mathrm{H}, 2 \mathrm{H}_{f, f^{\prime}}\right), 8.85\left(\mathrm{~s}, 2 \mathrm{H}, 2 \mathrm{H}_{a, a^{\prime}}\right)$, $13.06(\mathrm{~s}, 2 \mathrm{H}, \mathrm{NH})$ ppm (Figure S3, Supplementary Materials); ${ }^{13} \mathrm{C} \mathrm{NMR}$ (DMSO- $\left.d_{6}\right): \delta 55.51\left(\mathrm{OCH}_{3}\right)$, $127.33\left(C_{d, d^{\prime}}\right), 127.94\left(C_{b, b^{\prime}}\right), 139.74\left(C_{c, c^{\prime}}\right), 140.65\left(C_{f, f^{\prime}}\right), 147.51\left(C_{a, a^{\prime}}\right), 162.98(C-O M e), 171.81,175.50\left(C_{3,5}\right)$ ppm (Figure S3, Supplementary Materials).

Caution: Although no explosion hazard was noted during the experimental work, caution should be considered when handling complexes containing perchlorate.

\subsection{Crystal Structure Determination}

The crystallographic measurements were made for complexes 1 and 2 using a Bruker D8 Quest diffractometer with monochromated graphite Mo-K $\alpha$ radiation. Absorption corrections were performed by SADABS [38]. Using olex2 [39], the structure of complex 1 was solved and refined using the ShelXS [40] program package. The structure of complex 2 was solved using the Bruker APEX III program system and the SHELXTL program package [41,42]. The crystal data and structure refinement details are listed in Table 1. Quantitative analyses of molecular packing were performed using Hirshfeld analysis [43-47] with the aid of Crystal Explorer 17.5 program [48].

Table 1. Crystal data and structure refinement for the studied complexes.

\begin{tabular}{|c|c|c|}
\hline & 1 & 2 \\
\hline Empirical formula & $\mathrm{C}_{28} \mathrm{H}_{34} \mathrm{CdCl}_{2} \mathrm{~N}_{14} \mathrm{O}_{10}$ & $\mathrm{C}_{32} \mathrm{H}_{42} \mathrm{Cd}_{2} \mathrm{Cl}_{4} \mathrm{~N}_{18} \mathrm{O}_{20}$ \\
\hline Formula weight & $910.00 \mathrm{~g} / \mathrm{mol}$ & $1365.43 \mathrm{~g} / \mathrm{mol}$ \\
\hline Temperature (K) & 293(2) & 293(2) \\
\hline Crystal system & Orthorhombic & Monoclinic \\
\hline Space group & Cmca & $\mathrm{P} 2{ }_{1} / \mathrm{n}$ \\
\hline a $(\AA)$ & 32.032(19) & $11.183(2)$ \\
\hline $\mathrm{b}(\AA)$ & 15.181(9) & $28.562(6)$ \\
\hline$c(\AA)$ & $16.441(10)$ & $16.683(3)$ \\
\hline$\alpha\left(^{\circ}\right)$ & 90 & 90 \\
\hline$\beta\left(^{\circ}\right)$ & 90 & 104.019 \\
\hline$\gamma\left({ }^{\circ}\right)$ & 90 & 90 \\
\hline Volume $\left(\AA^{3}\right)$ & 7995(8) & $5170(2)$ \\
\hline $\mathrm{Z}$ & 8 & 4 \\
\hline$\rho_{\text {calc }} \mathrm{g}\left(\mathrm{cm}^{3}\right)$ & 1.512 & 1.754 \\
\hline$\mu\left(\mathrm{mm}^{-1}\right)$ & 0.748 & 1.119 \\
\hline $\mathrm{F}(000)$ & 3696 & 2736 \\
\hline Crystal size $\left(\mathrm{mm}^{3}\right)$ & $0.31 \times 0.24 \times 0.13$ & $0.30 \times 0.06 \times 0.02$ \\
\hline Radiation & \multicolumn{2}{|c|}{$\operatorname{MoK} \alpha(\lambda=0.71073 \AA)$} \\
\hline $2 \theta$ range for data collection/ ${ }^{\circ}$ & 4.96 to 50.00 & 4.72 to 52.74 \\
\hline Index ranges & $-37 \leq \mathrm{h} \leq 38,-18 \leq \mathrm{k} \leq 18,-19 \leq 1 \leq 19$ & $-13 \leq \mathrm{h} \leq 13,-35 \leq \mathrm{k} \leq 35,-20 \leq 1 \leq 20$ \\
\hline Reflections collected & 91,955 & 168,280 \\
\hline Independent reflections & $3588\left(\mathrm{R}_{\mathrm{int}}=0.0950\right)$ & $10515(\mathrm{R}(\mathrm{int})=0.0881)$ \\
\hline Data/restraints/parameters & $3588 / 0 / 259$ & $10515 / 18 / 731$ \\
\hline Goodness-of-fit on $\mathrm{F}^{2}$ & 1.115 & 1.064 \\
\hline Final $R$ indexes $(I>=2 \sigma(I))$ & $\mathrm{R}_{1}=0.0803, \mathrm{wR}_{2}=0.1636$ & $\mathrm{R} 1=0.0406, \mathrm{wR} 2=0.0936$ \\
\hline Final R indexes (all data) & $\mathrm{R}_{1}=0.1211, \mathrm{wR}_{2}=0.1883$ & $\mathrm{R} 1=0.0571, \mathrm{wR} 2=0.1007$ \\
\hline Largest diff. peak/hole $\left(\mathrm{e} \AA^{-3}\right)$ & $0.87 /-0.42$ & $0.696 /-0.530$ \\
\hline CCDC & $1,906,764$ & $1,906,765$ \\
\hline
\end{tabular}

\subsection{Computational Details}

Single-point calculations on the X-ray structure of complexes 1 and $\mathbf{2}$ were performed using Gaussian 09 software [49]. The WB97XD [50] method combined with 6-311G(d,p) and LANL2DZ 
basis sets for nonmetals and $\mathrm{Cd}$, respectively, were used for this task. Natural bond orbital (NBO) calculations were performed using the Gaussian 09 built-in NBO 3.1 [51] program. The Multiwfn [52] program was used to compute the atoms in molecules (AIM) topological parameters.

\section{Results and Discussion}

\subsection{Crystal Structure Description}

The molecular structure and atom numbering of the homoleptic $\left[\mathrm{Cd}(\mathrm{BDMPT})_{2}\right]\left(\mathrm{ClO}_{4}\right)_{2}$ complex (1) are illustrated in Figure 2. The structure crystallized in the orthorhombic crystal system and Cmca space group with $Z=8$. It should be noted that only half of the complex is crystallographically independent; thus, the asymmetric unit of this complex comprised half of its molecular formula. The structure showed a pincer-type complex with two tridentate ligand (BDMPT) units coordinating the central metal ion (Cd(II)) in the inner sphere and two ionic perchlorate anions in the outer sphere. Each BDMPT ligand coordinating the Cd(II) ion via one N-atom from the s-triazine core (Cd1-N3; 2.331(2) $\AA$ ) and one $\mathrm{N}$-atom from each pyrazole moieties with Cd1-N1 and Cd1-N7 distances of 2.403(6) and 2.373(6) $\AA$, respectively (Table 2). The former was found generally shorter than the two latter bonds indicating the stronger $\mathrm{Cd}-\mathrm{N}$ (triazine) interaction than $\mathrm{Cd}-\mathrm{N}$ (pyrazole). The two ligand molecules coordinating $\mathrm{Cd}(\mathrm{II})$ in a meridional fashion with trans $\mathrm{N}-\mathrm{Cd}-\mathrm{N}$ angles varied significantly (114.4(3)-175.9(2) $)^{\circ}$. As a result, the Cd(II) showed a hexa-coordinated environment with a highly distorted configuration compared to any of the well-known ideal geometries, trigonal prism and octahedral (Figure 2). With the aid of the continuous shape measure (CShM) tool [53-56], the values of the CShM are 12.6 and 12.5 against the perfect octahedron and trigonal prism, respectively. The almost equal and large values of the CShM in both cases confirmed that the coordination geometry around the $\mathrm{Cd}(\mathrm{II})$ ion is an intermediate case between the two extremes.
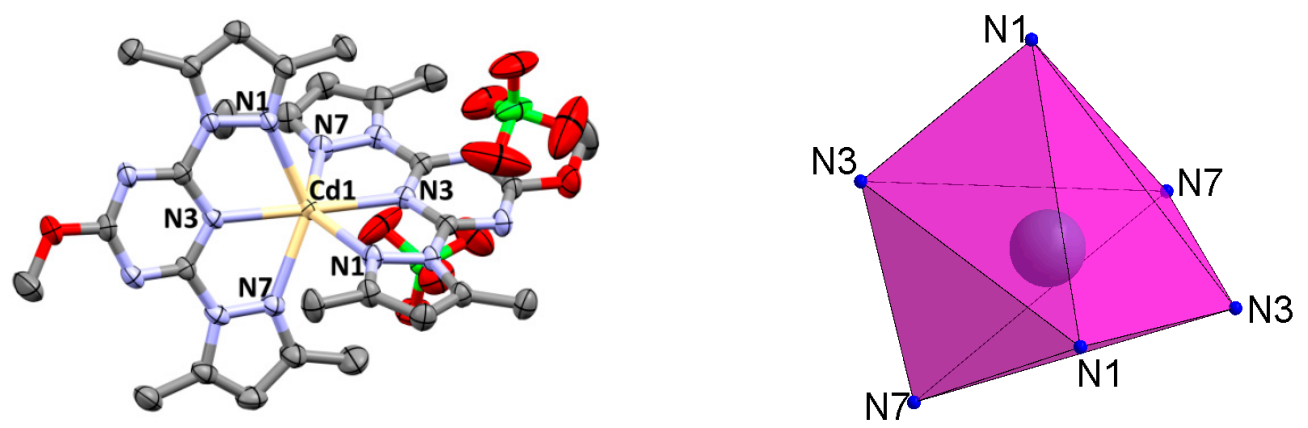

Figure 2. Structure showing the most relevant atom numbering (left) and the distorted octahedron (right) of complex 1 .

Table 2. Bond lengths $(\AA)$ and angles $\left(^{\circ}\right)$ for complex 1.

\begin{tabular}{|c|c|c|c|}
\hline Bond Length & & & \\
\hline Cd1-N1 & $2.403(6)$ & Cd1-N7 & $2.373(6)$ \\
\hline Cd1-N3 & $2.331(5)$ & & \\
\hline \multicolumn{4}{|l|}{ Bond Angle } \\
\hline $\mathrm{N} 1-\mathrm{Cd} 1-\mathrm{N} 1^{1}$ & $114.4(3)$ & N3 ${ }^{1}-\mathrm{Cd} 1-\mathrm{N} 7$ & $114.8(2)$ \\
\hline $\mathrm{N} 3^{1}-\mathrm{Cd} 1-\mathrm{N} 1$ & $110.97(18)$ & N3-Cd1-N7 & $67.3(2)$ \\
\hline N3-Cd1-N1 & $66.66(18)$ & N7-Cd1-N1 1 & $80.3(2)$ \\
\hline N3-Cd1-N1 1 & $110.97(18)$ & $\mathrm{N} 7^{1}-\mathrm{Cd} 1-\mathrm{N} 1^{1}$ & $133.93(19)$ \\
\hline $\mathrm{N} 3^{1}-\mathrm{Cd} 1-\mathrm{N} 1^{1}$ & $66.66(18)$ & N71_-Cd1-N1 & $80.3(2)$ \\
\hline $\mathrm{N} 3^{1}-\mathrm{Cd} 1-\mathrm{N} 3$ & $175.9(2)$ & N7 ${ }^{1}-\mathrm{Cd} 1-\mathrm{N} 7$ & $121.9(3)$ \\
\hline $\mathrm{N} 3^{1}-\mathrm{Cd} 1-\mathrm{N}^{1}$ & $67.3(2)$ & & \\
\hline
\end{tabular}


The structure of the coordinated ligand molecule showed slight deviations in the two pyrazole moieties from co-planarity with the $s$-triazine core. The two pyrazole moieties deviated only by $3.48-3.58^{\circ}$ from the mean plane of the $s$-triazine core. The maximum distance between the $s$-triazine mean plane and any atom in the pyrazole moieties did not exceed $0.249 \AA$ A. Moreover, the two ligand molecules coordinating the $\mathrm{Cd}(\mathrm{II})$ ion are not fully perpendicular with each other, which explained the strong distortion of the coordination environment around $\mathrm{Cd}(\mathrm{II})$. The angle between the two mean planes passing through each ligand molecule was found to be $62.2^{\circ}$. Such a situation left large spaces between the complex cation units (Figure 3A) which were found occupied by the perchlorate anions. The latter connected the complex units by weak $\mathrm{C}-\mathrm{H} \cdots$ O hydrogen bonds, as shown in Figure $3 \mathrm{~B}$ and listed in Table 3. The anion- $\pi$-stacking interaction is another feature of molecular packing in the crystal structure of 1 . The s-triazine ring has two perchlorate anions found below and above it, with $\mathrm{C} \cdots \mathrm{O}$ contact distances of $3.179,3.171$, and $3.139 \AA$ for the $\mathrm{C} 6 \cdots \mathrm{O} 1, \mathrm{C} 7 \cdots \mathrm{O} 1$, and $\mathrm{C} 8 \cdots \mathrm{O} 4$ interactions, respectively. Presentation of these interactions is shown in Figure 4.

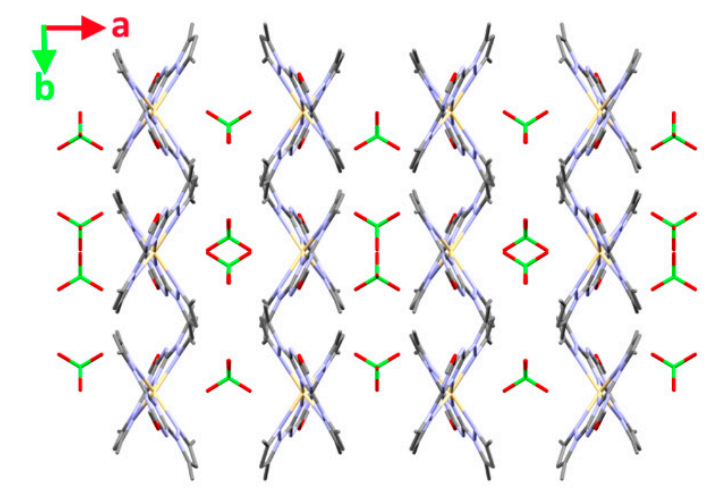

A

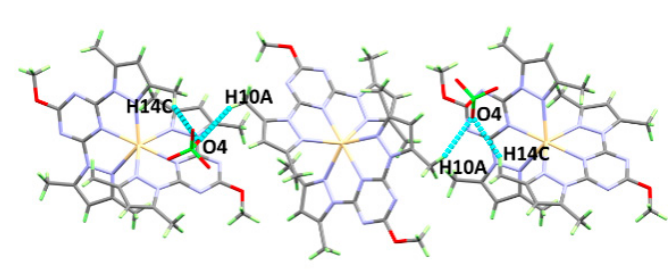

B

Figure 3. Packing of the complex cations and perchlorate anions along the $a b$ plane (A) and the weak $\mathrm{C}-\mathrm{H} \cdots \mathrm{O}$ hydrogen-bonding interactions connecting the complex units (B).

Table 3. Hydrogen bonds $\left(\AA\right.$ and $\left.^{\circ}\right)$ for complex $\mathbf{1}$.

\begin{tabular}{ccc}
\hline D-H $\cdots \mathbf{A}$ & $\mathbf{D} \cdots \mathbf{A}(\mathbf{A})$ & $\mathbf{D}-\mathbf{H} \cdots \mathbf{A}\left({ }^{\circ}\right)$ \\
\hline $\mathrm{C} 14-\mathrm{H} 14 \mathrm{C} \cdots \mathrm{O} 4(\mathrm{i})$ & $3.492(12)$ & $145.9(6)$ \\
$\mathrm{C} 10-\mathrm{H} 10 \mathrm{~A} \cdots \mathrm{O} 4(\mathrm{ii})$ & $3.551(13)$ & $154.7(6)$ \\
\hline
\end{tabular}

(i) $1-\mathrm{x}, 1-\mathrm{y}, 1-\mathrm{z}$; (ii) $1-\mathrm{x}, 1 / 2+\mathrm{y}, 1.5-\mathrm{z}$.

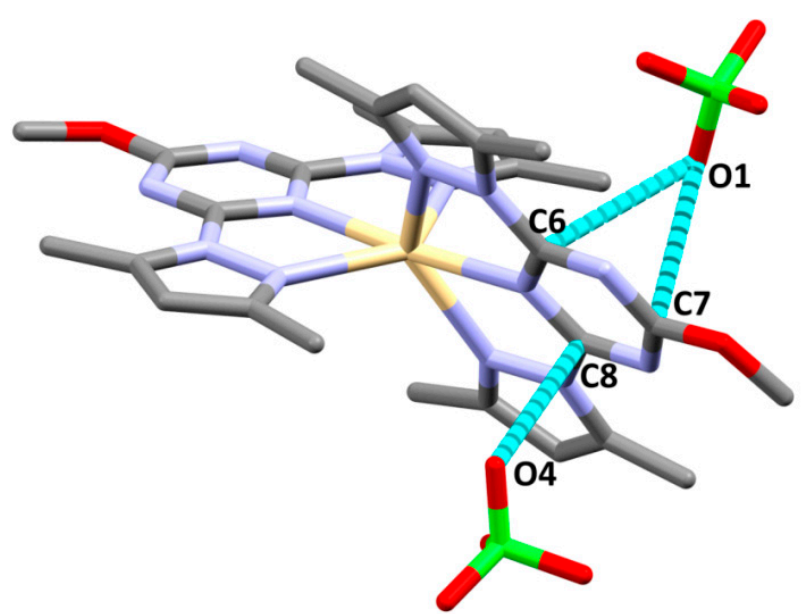

Figure 4. The possible perchlorate- $\pi$-stacking interactions in $\mathbf{1}$. 
The crystal structure of the dinuclear $\left[\mathrm{Cd}_{2}(\mathrm{MBPT})_{2}\left(\mathrm{H}_{2} \mathrm{O}\right)_{2} \mathrm{Cl}\right]\left(\mathrm{ClO}_{4}\right)_{3} \cdot 4 \mathrm{H}_{2} \mathrm{O}$ complex 2 comprised one formula unit per asymmetric unit and four molecules per unit cell. It crystallized in the monoclinic crystal system and the centrosymetric $\mathrm{P} 2_{1} / \mathrm{n}$ space group. The experimental geometric parameters (bond lengths and angles) are listed in Table 4 . This complex showed two hepta-coordinated Cd(II) centers with a distorted pentagonal bipyramidal coordination geometry. While the outer sphere contained three perchlorate anions and four crystallization water molecules, the inner sphere comprised two ligands (MBPT) acting as pentadentate $\mathrm{N}$-chelate via one $\mathrm{N}$ from the s-triazine core, two $\mathrm{N}$-atoms from the hydrazone and two $\mathrm{N}$-atoms from the pyridyl moieties which coordinated the $\mathrm{Cd}(\mathrm{II})$ center in a pincer-like fashion (Figure 5). The axial positions are occupied by one terminal water molecule and one bridged chloride connecting the two Cd-centers. The Cd1-Cl1-Cd2 angle is $132.21^{\circ}$ and the two Cd1-O1 (2.325(4) $⿱$ ) and Cd2-O2 (2.322(4) $\mathrm{A})$ bond distances are identical. Due to such a bent bridged structure, the two MBPT molecules are not parallel to one another and the ligand (MBPT) molecules favored an anti-configuration to each other to minimize the steric repulsion between the two bulky organic ligands. Moreover, the $\mathrm{Cd}-\mathrm{N}$ (triazine) bonds are shorter than any of the $\mathrm{Cd}-\mathrm{N}$ (hydrazone) and $\mathrm{Cd}-\mathrm{N}$ (pyridine) bonds. It is found that the two pyridyl moieties are significantly twisted from one another due to the short distance between the hydrogen atoms at the 6-position. The H1 $\cdots \mathrm{H} 15$ and H17 $\cdots \mathrm{H} 31$ intramolecular distances are 2.332 and $2.255 \AA$, respectively. In the Cd1-MBPT unit, the angles between the mean plane of the $s$-triaizne core and the plane passing through the pyridine moieties are $11.7^{\circ}\{\mathrm{N} 1 \mathrm{C} 1 \mathrm{C} 2 \mathrm{C} 3 \mathrm{C} 4 \mathrm{C} 5\}$ and $12.8^{\circ}\{\mathrm{C} 15 \mathrm{C} 14 \mathrm{C} 13 \mathrm{C} 12 \mathrm{C} 11 \mathrm{~N} 9\}$, while the corresponding values for the Cd2-MBPT unit are $6.1^{\circ}\{\mathrm{C} 17 \mathrm{~N} 10 \mathrm{C} 21 \mathrm{C} 20 \mathrm{C} 19 \mathrm{C} 18\}$ and $12.1^{\circ}\{\mathrm{C} 29 \mathrm{C} 28 \mathrm{C} 27 \mathrm{~N} 18 \mathrm{C} 31 \mathrm{C} 30\}$, indicating the twist of the two ligand strands from one another.

Table 4. Bond lengths $(\AA)$ and angles $\left(^{\circ}\right)$ for complex 2.

\begin{tabular}{|c|c|c|c|c|c|}
\hline Bond Length & & & & & \\
\hline Cd1-O1 & $2.325(4)$ & Cd1-N9 & $2.436(3)$ & Cd2-N17 & $2.450(3)$ \\
\hline Cd1-N4 & $2.374(3)$ & Cd1-Cl1 & $2.6195(11)$ & $\mathrm{Cd} 2-\mathrm{N} 10$ & $2.464(3)$ \\
\hline Cd1-N2 & $2.441(3)$ & $\mathrm{Cd} 2-\mathrm{O} 2$ & $2.322(4)$ & Cd2-N18 & $2.402(3)$ \\
\hline Cd1-N8 & $2.435(3)$ & $\mathrm{Cd} 2-\mathrm{N} 13$ & $2.389(3)$ & $\mathrm{Cd} 2-\mathrm{Cl1}$ & 2.6153(11) \\
\hline Cd1-N1 & $2.381(3)$ & Cd2-N11 & $2.429(3)$ & & \\
\hline \multicolumn{6}{|l|}{ Bond Angle } \\
\hline O1-Cd1-N4 & 91.34(14) & O1-Cd1-Cl1 & 176.91(12) & N13-Cd2-N11 & $64.38(10)$ \\
\hline O1-Cd1-N1 & $87.26(14)$ & N4-Cd1-Cl1 & $91.49(8)$ & $\mathrm{O} 2-\mathrm{Cd} 2-\mathrm{N} 17$ & 83.63(13) \\
\hline N4-Cd1-N1 & $131.12(11)$ & N1-Cd1-Cl1 & $89.95(9)$ & N18-Cd2-N17 & $67.08(11)$ \\
\hline O1-Cd1-N8 & $96.97(13)$ & N8-Cd1-Cl1 & $85.36(8)$ & $\mathrm{O} 2-\mathrm{Cd} 2-\mathrm{N} 10$ & $83.53(14)$ \\
\hline N4-Cd1-N8 & $64.52(10)$ & N9-Cd1-Cl1 & $96.61(8)$ & N18-Cd2-N10 & $99.21(11)$ \\
\hline N1-Cd1-N8 & $163.90(11)$ & N2-Cd1-Cl1 & $100.15(8)$ & N17-Cd2-N10 & $161.03(11)$ \\
\hline O1-Cd1-N9 & $82.52(13)$ & $\mathrm{Cd} 2-\mathrm{Cl1}-\mathrm{Cd} 1$ & $132.21(4)$ & N13-Cd2-Cl1 & $91.45(9)$ \\
\hline N4-Cd1-N9 & $129.62(11)$ & $\mathrm{O} 2-\mathrm{Cd} 2-\mathrm{N} 18$ & $90.79(15)$ & $\mathrm{N} 11-\mathrm{Cd} 2-\mathrm{Cl1}$ & $84.54(8)$ \\
\hline N1-Cd1-N9 & $98.63(12)$ & N18-Cd2-N11 & $164.58(11)$ & N10-Cd2-Cl1 & 93.45(9) \\
\hline N8-Cd1-N9 & $66.73(11)$ & N13-Cd2-N17 & $63.85(10)$ & $\mathrm{O} 2-\mathrm{Cd} 2-\mathrm{Cl1}$ & $176.86(10)$ \\
\hline $\mathrm{O} 1-\mathrm{Cd} 1-\mathrm{N} 2$ & $79.99(12)$ & N11-Cd2-N17 & 128.14(11) & N18-Cd2-Cl1 & $90.56(9)$ \\
\hline $\mathrm{N} 4-\mathrm{Cd} 1-\mathrm{N} 2$ & $64.18(10)$ & $\mathrm{N} 13-\mathrm{Cd} 2-\mathrm{N} 10$ & $129.96(11)$ & $\mathrm{N} 17-\mathrm{Cd} 2-\mathrm{Cl1}$ & $99.51(8)$ \\
\hline N1-Cd1-N2 & $67.50(11)$ & N11-Cd2-N10 & 66.61(11) & $\mathrm{O} 2-\mathrm{Cd} 2-\mathrm{N} 13$ & $89.83(16)$ \\
\hline N8-Cd1-N2 & $128.49(11)$ & O2-Cd2-N11 & $93.44(14)$ & & \\
\hline N9-Cd1-N2 & $158.07(10)$ & N13-Cd2-N18 & $130.52(11)$ & & \\
\hline
\end{tabular}

The complex molecules are packed in the crystal via sets of $\mathrm{N}-\mathrm{H} \cdots \mathrm{N}, \mathrm{N}-\mathrm{H} \cdots \mathrm{O}$, and $\mathrm{O}-\mathrm{H} \cdots \mathrm{O}$ hydrogen-bonding interactions, as listed in Table 5 . The $\mathrm{N}-\mathrm{H} \cdots \mathrm{N}$ hydrogen bonds connected the coordinated organic ligand molecules in two neighboring complex cations. Moreover, the perchlorate anions and water molecules connected the complex cations via the $\mathrm{N}-\mathrm{H} \cdots \mathrm{O}$ and $\mathrm{O}-\mathrm{H} \cdots \mathrm{O}$ hydrogen bonds (Figure 6). 


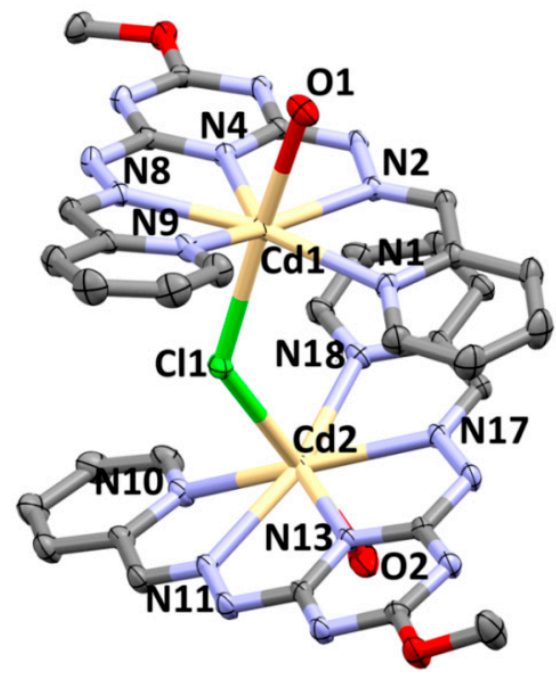

Figure 5. The structure and atom numbering of the asymmetric unit of $\mathbf{2}$. All hydrogen atoms, crystal water molecules, and perchlorate anions were omitted for more clarity.

Table 5. The hydrogen-bond parameters $\left(\AA,^{\circ}\right)$ in the crystal structure of 2 .

\begin{tabular}{|c|c|c|}
\hline D-H $\cdots A$ & D $\cdots A$ & D-H $\cdots A$ \\
\hline 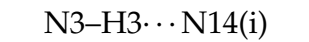 & 2.941(5) & $164.7(2)$ \\
\hline N12-H12A $\cdots$ N5(i) & $2.891(5)$ & $151.0(2)$ \\
\hline 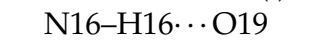 & $2.812(6)$ & $167.7(3)$ \\
\hline N7-H7 ‥O17 & $2.749(5)$ & $165.8(2)$ \\
\hline O1-H1B $\cdots$ O5(ii) & $3.107(8)$ & $150.5(4)$ \\
\hline O1-H1A $\cdots$ O18 & $2.716(7)$ & $159.7(1)$ \\
\hline $\mathrm{O} 2-\mathrm{H} 2 \mathrm{~B} \cdots \mathrm{O} 10$ & $2.798(7)$ & 168.7(3) \\
\hline $\mathrm{O} 2-\mathrm{H} 2 \mathrm{~A} \cdots \mathrm{O} 13$ & $2.730(2)$ & 134.3(1) \\
\hline O18-H18A… O14(iii) & $3.025(9)$ & $123.1(2)$ \\
\hline O18-H18B $\cdots$ O20(iv) & $2.900(1)$ & $149.2(7)$ \\
\hline O17-H17B ‥ O7(v) & $3.422(8)$ & $145.5(3)$ \\
\hline O17-H17B $\cdots$ O6(v) & $3.024(8)$ & $154.3(4)$ \\
\hline $\mathrm{O} 19-\mathrm{H} 19 \mathrm{~B} \cdots \mathrm{O} 20$ & $2.799(8)$ & $154.6(6)$ \\
\hline
\end{tabular}

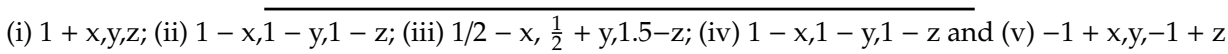

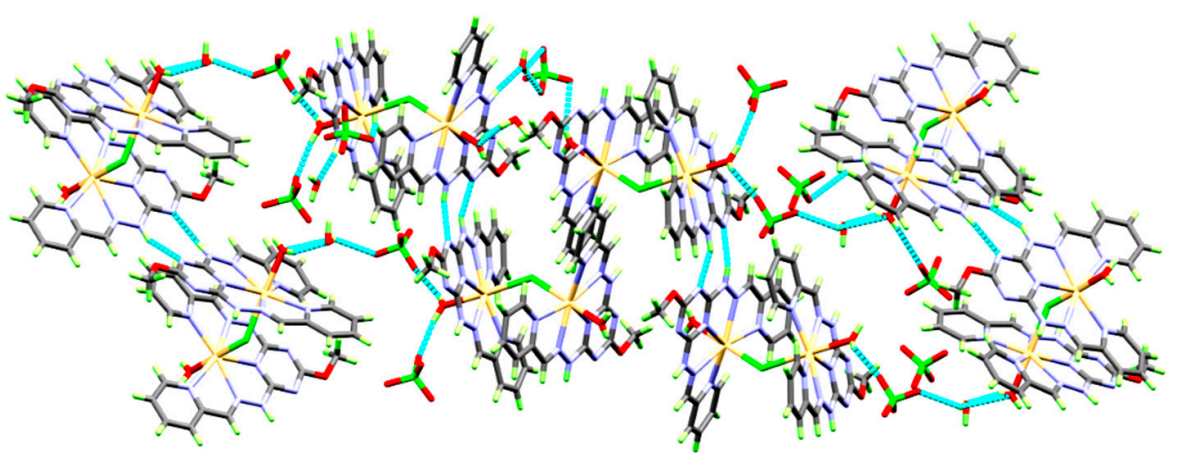

Figure 6. Part of the hydrogen-bond network connecting the complex units via $\mathrm{N}-\mathrm{H} \cdots \mathrm{N}, \mathrm{N}-\mathrm{H} \cdots \mathrm{O}$, and $\mathrm{O}-\mathrm{H} \cdots \mathrm{O}$ hydrogen bonds.

\subsection{Analysis of Molecular Packing}

Hirshfeld surfaces mapped over $\mathrm{d}_{\text {norm }}$, shape index (SI), and curvedness for the $\left[\mathrm{Cd}(\mathrm{BDMPT})_{2}\right]^{2+}$ and $\left[\mathrm{Cd}_{2}(\mathrm{MBPT})_{2}\left(\mathrm{H}_{2} \mathrm{O}\right)_{2} \mathrm{Cl}\right]^{3+}$ units of complexes $\mathbf{1}$ and 2, respectively, are shown in Figure S4 (Supplementary Materials). A summary of the most important contacts and their percentages are shown in Figure 7. 


\section{Complex 1 Complex 2}

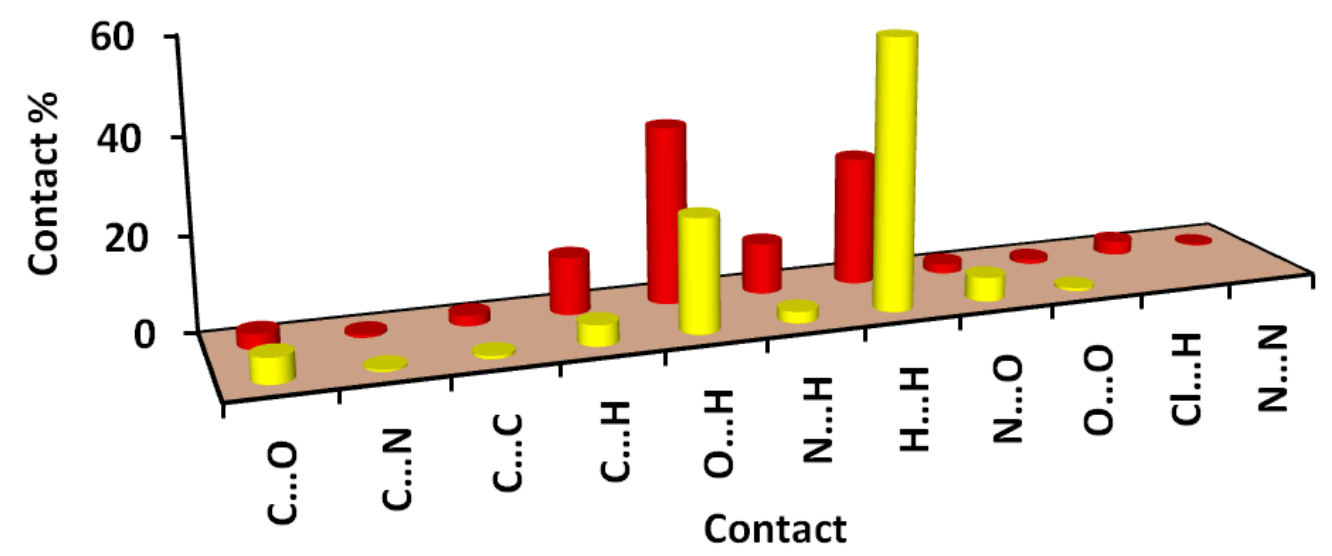

Figure 7. Summary of the intermolecular interactions and their percentages in the crystal structure of the studied complexes.

It is clear that the packing of complex units in the crystal is dominated mainly by $\mathrm{H} \cdots \mathrm{H}$ and $\mathrm{O} \cdots \mathrm{H}$ contacts for complex 1 . All these interactions appeared as red spots in the $\mathrm{d}_{\text {norm }}$ Hirshfeld surface (Figure 8 ). The contributions of these contacts are $57.2 \%$ and $24.0 \%$ of the whole fingerprint area, respectively. The minimum $\mathrm{H} \cdots \mathrm{H}$ and $\mathrm{O} \cdots \mathrm{H}$ contact distances are $2.290 \AA$ ( $\mathrm{H} 9 \mathrm{~A} \cdots \mathrm{H} 9 \mathrm{C})$ and $2.549 \AA(\mathrm{O} 4 \cdots \mathrm{H} 10 \mathrm{~A})$, respectively. In addition, the presence of $\mathrm{C} \cdots \mathrm{O}$ contacts $(5.3 \%)$ confirmed the anion- $\pi$-stacking interactions between the free perchlorate anion and the $s$-triazine moiety with shortest contact distance of $3.139 \AA$ (C8 ‥ O 4$)$.
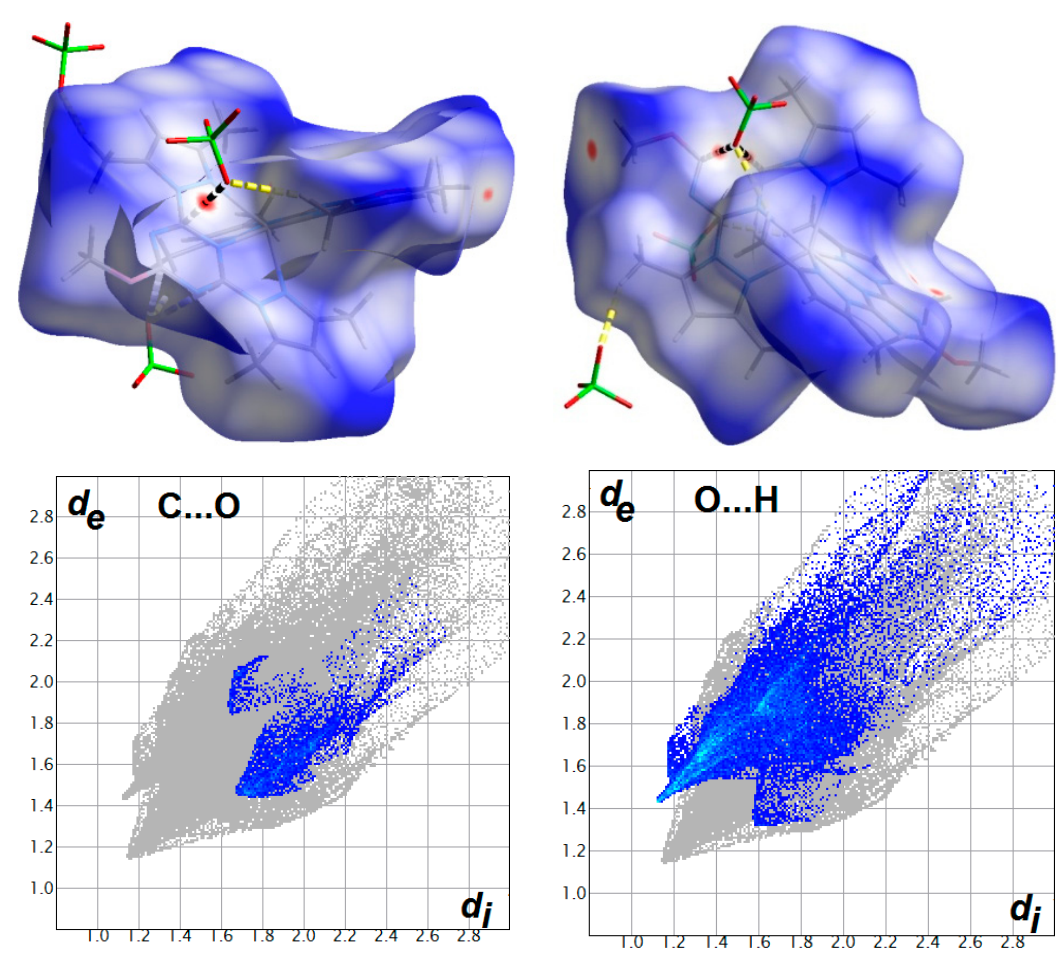

Figure 8. The most important intermolecular contacts in the crystal structure of complex 1. The $\mathrm{O} \cdots \mathrm{H}$ and $\mathrm{C} \cdots \mathrm{O}$ contacts are indicated by yellow and black dotted lines, respectively.

On the other hand, the packing of the complex units of 2 in its crystal is dominated mainly by strong $\mathrm{O} \cdots \mathrm{H}$ and $\mathrm{N} \cdots \mathrm{H}$ hydrogen bonds where all appeared as red regions in the $\mathrm{d}_{\text {norm }}$ map, as well as sharp spikes in the decomposed fingerprint plots. Presentation of the $d_{\text {norm }}$ surfaces and 
fingerprint plots of these interactions is shown in Figure 9. The percentages of the $\mathrm{O} \cdots \mathrm{H}$ and $\mathrm{N} \cdots \mathrm{H}$ contacts are $37.4 \%$ and $10.8 \%$ of the whole fingerprint area, respectively. It is obvious that, the common $\mathrm{H} \cdots \mathrm{H}$ contacts contributed less in the molecular packing of this complex $(27.2 \%)$ compared to 1 . In complex 2, the $\mathrm{N}-\mathrm{H} \cdots \mathrm{O}$ hydrogen bridges are the shortest $\mathrm{O} \cdots \mathrm{H}$ contacts, where the $\mathrm{O} 17 \cdots \mathrm{H} 7$ and O19 $\cdots$ H16 contact distances were found to be $1.764 \AA$ and $1.820 \AA$, respectively, using Hirshfeld analysis. The $\mathrm{N} \cdots \mathrm{H}$ hydrogen bridges occurred among each two neighbouring complex units via the $\mathrm{NH}$ group as the $\mathrm{H}$-bond donor and one of the $s$-triazine $\mathrm{N}$-atoms as the $\mathrm{H}$-bond acceptor. The $\mathrm{N} \cdots \mathrm{H}$

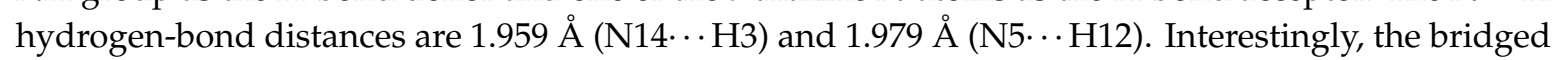
chloride ion not only connected the two $\mathrm{Cd}$ (II) centres but also connected the complex units via two $\mathrm{Cl} \cdots \mathrm{H}$ hydrogen bridges $(2.9 \%)$ : one with the protons from the crystal water and the other from the hydrazone $\mathrm{N}=\mathrm{CH}$ group of a neighbouring organic ligand. The $\mathrm{Cl} \cdots \mathrm{H}$ contact distances were found to be $2.407 \AA$ and $2.607 \AA$ for the $\mathrm{Cl1} \cdots \mathrm{H} 17 \mathrm{~A}$ and $\mathrm{Cl} 1 \cdots \mathrm{H} 10$ contacts, respectively. It is worth noting that both complexes showed some weak $\mathrm{C} \cdots \mathrm{H}$ interactions, where all appeared as blue regions in the $d_{\text {norm }}$ surface, indicating the lower importance of this type of contact in the molecular packing of the studied complexes. Curvedness and shape index maps did not show any signs of $\pi-\pi$ stacking interactions in both complexes (Figure S4, Supplementary Materials).

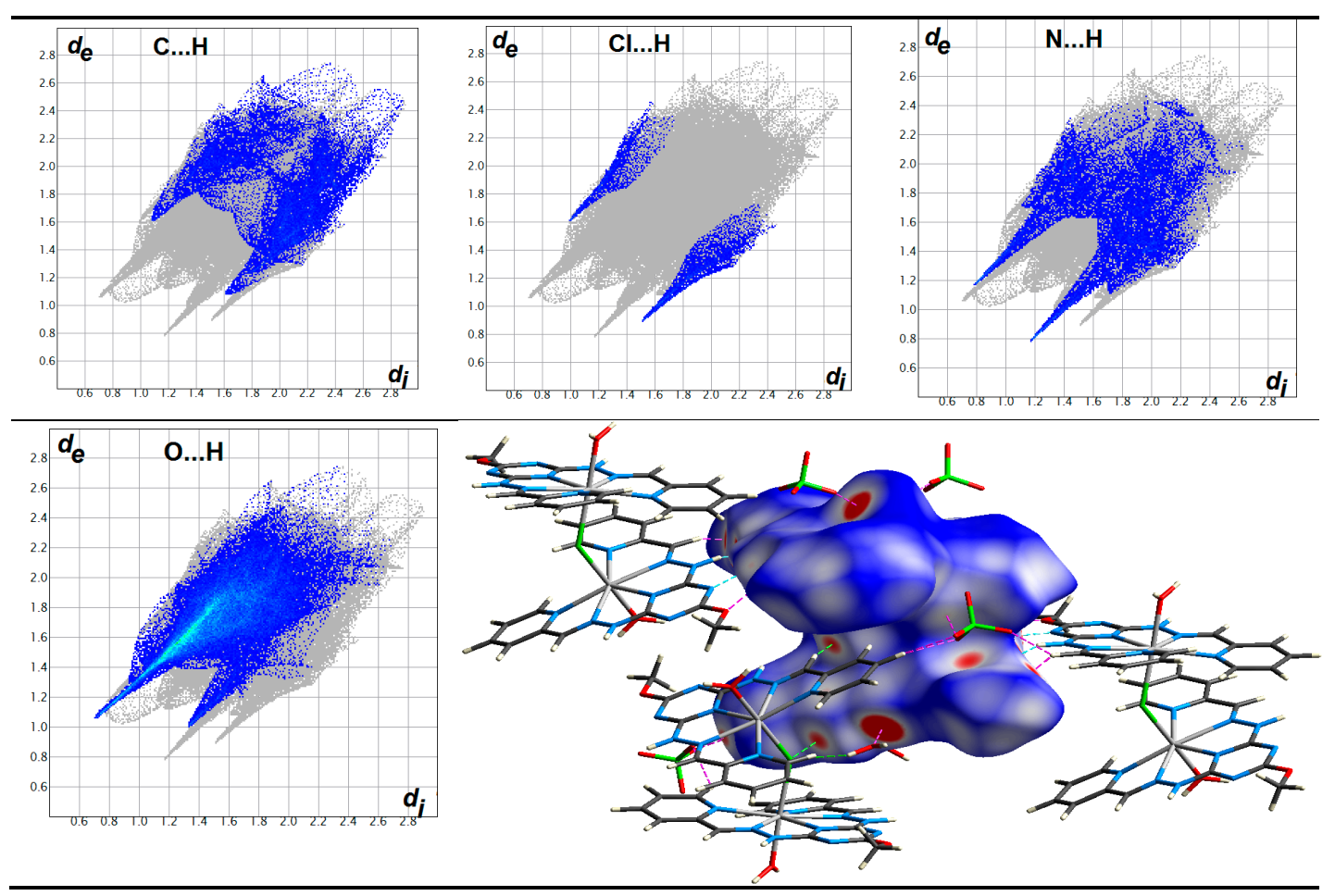

Figure 9. The most important intermolecular contacts in the crystal structure of complex 2. The $\mathrm{O} \cdots \mathrm{H}$, $\mathrm{N} \cdots \mathrm{H}$, and $\mathrm{Cl} \cdots \mathrm{H}$ are indicated by purple, turquoise, and green colors, respectively. The hydrophobic C ... H interactions appeared weak and were omitted from this illustration for better clarity.

\subsection{Vibrational Spectra and TGA Analysis}

The FTIR spectra of complexes $\mathbf{1}$ and $\mathbf{2}$ are shown in Figure S1 (Supplementary Materials). It is clear that the $v_{(\mathrm{C}=\mathrm{N})}$ mode appeared at $1619 \mathrm{~cm}^{-1}$ in both complexes, while it appeared at $1593 \mathrm{~cm}^{-1}$ and $1625 \mathrm{~cm}^{-1}$ for the free BDMPT and MBPT, respectively. On other hand, the $v_{(\mathrm{C}=\mathrm{C})}$ modes showed little variations due to complexation of $\mathrm{Cd}$ (II) with the organic ligand. The $v_{(\mathrm{C}=\mathrm{C})}$ modes appeared at a lower wavenumber of $1543 \mathrm{~cm}^{-1}$ for complex 1 compared to $1555 \mathrm{~cm}^{-1}$ in the free ligand. The corresponding vibrational wavenumbers for complex 2 are 1586 and $1537 \mathrm{~cm}^{-1}$ compared to 1586 and $1544 \mathrm{~cm}^{-1}$ for the free MBPT. The perchlorate vibrations appeared as a triple split band in the regions of $1136-1056 \mathrm{~cm}^{-1}$ and $1160-1077 \mathrm{~cm}^{-1}$ for complexes $\mathbf{1}$ and $\mathbf{2}$, respectively. 
TGA analyses of the free ligands (BDMPT and MBPT) compared to the corresponding Cd(II) complexes (1 and 2, respectively) are shown in Figure 10. Both ligands started the mass loss in the temperature range of $60-67^{\circ} \mathrm{C}$, which is probably attributed to the evaporation of solvent or moisture contained in the sample, before starting to decompose in several steps at 185 and $235^{\circ} \mathrm{C}$ for BDMPT and MBPT, respectively. On other hand, complex 1 started to decompose thermally at $273^{\circ} \mathrm{C}$. The first step in the temperature range of $273-369^{\circ} \mathrm{C}$ showed a large mass loss of $34.7 \%$ (calculated $32.9 \%$ ), probably due to the decomposition of one of the coordinated ligands, followed by a slow decomposition of the complex residue up to $800^{\circ} \mathrm{C}$. In case of complex 2, the first small step in the temperature range of $81-121^{\circ} \mathrm{C}$ corresponded to the loss of six water molecules with an experimental mass loss of $8.3 \%$ (calculated $7.9 \%$ ). The remaining complex residue showed good thermal stability as indicated by the long flat plateau until $273^{\circ} \mathrm{C}$. After that, a sudden large mass loss of $53.5 \%$ (calculated $51.2 \%$ ) occurred due to the decomposition of the organic ligand molecules up to $361^{\circ} \mathrm{C}$, followed by a slow decomposition of the complex residue up to $800^{\circ} \mathrm{C}$.
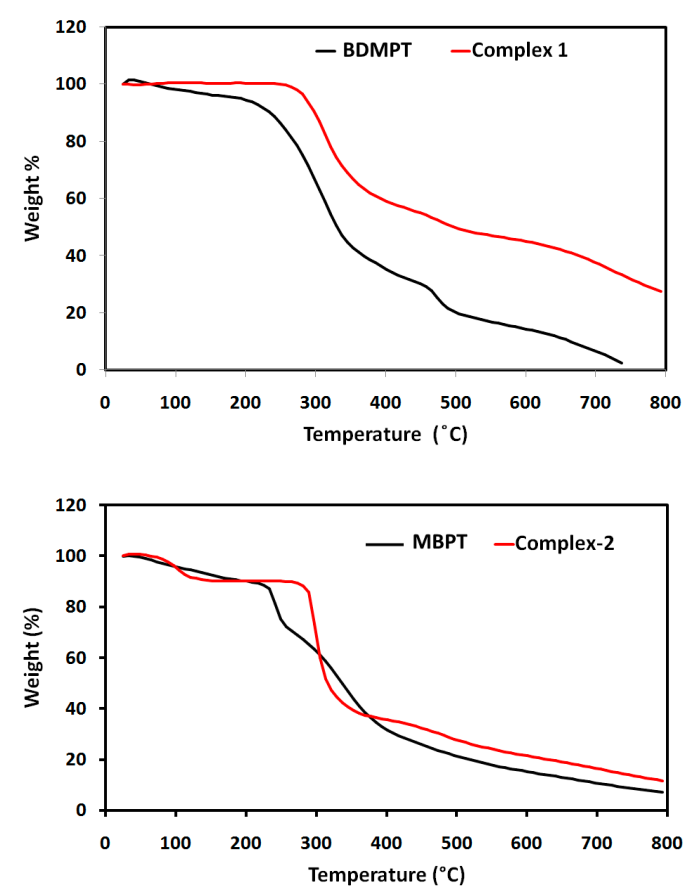

Figure 10. Thermogravimetric analyses of complexes 1 and 2 compared to the free ligands.

\subsection{Density Functional Theory (DFT) Studies}

In metal organic complexes, the interaction of metal ion $(\mathrm{Cd}(\mathrm{II}))$ with ligand groups leads to significant variations in their charge densities due to the electron transferences from the ligand as a Lewis base to the metal ion as a Lewis acid. A summary of the natural charges at cadmium and ligand groups in complexes $\mathbf{1}$ and $\mathbf{2}$ are collected in Table 6. The average net natural charges at the perchlorate counter anions are almost $-1.0 \mathrm{e}$, indicating insignificant interactions with the metal ion. The slight changes in the net charges of the perchlorate anions could be attributed to their interactions with the organic ligand via hydrogen bonds or anion- $\pi$-stacking interactions. On the other hand, the natural charges at the $\mathrm{Cd}$ ions decreased significantly by 0.535 e for $\mathrm{Cd} 1$ in complex 1 . The corresponding values for $\mathrm{Cd} 1$ and $\mathrm{Cd} 2$ in complex 2 are 0.641 and 0.618 e, respectively. In the former, the net electron density transferred from the two organic ligands is $0.484 \mathrm{e}$, while, in complex 2 , the electron density transferred to the two Cd-centers is almost the same ( 0.371 and $0.331 \mathrm{e}$, respectively). In addition, the coordinated chloride ( $\sim 0.290$ e) ligand transferred a significant amount of electron density to the two Cd-ions, while each of the coordinated water molecules transferred only 0.093 e (average value) to the central metal ion. 
Table 6. Natural charges at Cd and ligand groups calculated using WB97XD method and 6-311G(d,p) basis sets for nonmetal atoms and LANL2DZ for Cd.

\begin{tabular}{cccc}
\hline & $\mathbf{1}$ & & $\mathbf{2}$ \\
\hline $\mathrm{Cd} 1$ & 1.4646 & $\mathrm{Cd} 1$ & 1.3590 \\
& & $\mathrm{Cd} 2$ & 1.3819 \\
$\mathrm{ClO}_{4}^{-\mathrm{a}}$ & -0.9745 & $\mathrm{ClO}_{4}^{-\mathrm{a}}$ & -0.9726 \\
$\mathrm{BDMPT}^{\mathrm{a}}$ & 0.2422 & $\mathrm{MBPT}^{\mathrm{b}}$ & 0.3707 \\
& & $\mathrm{MBPT}^{\mathrm{c}}$ & 0.3315 \\
& & $\mathrm{H}_{2} \mathrm{O}(1)$ & 0.0935 \\
& & $\mathrm{H}_{2} \mathrm{O}(2)$ & 0.0918 \\
& & $\mathrm{Cl}(1)$ & -0.7103 \\
\hline a $^{\text {average value; }}{ }^{\mathrm{b}}$ lower $^{\mathrm{c}}$ and $^{\mathrm{c}}$ higher atom numbering
\end{tabular}

In order to quantify the strength of interactions between the $\mathrm{Cd}(\mathrm{II})$ and the ligand donor atoms, the interaction energies at the $\mathrm{Cd}-\mathrm{N}, \mathrm{Cd}-\mathrm{O}$, and $\mathrm{Cd}-\mathrm{Cl}$ bond critical points $(\mathrm{BCPs})$ were calculated in the framework of atoms in molecules topology analysis [57-64]. The results of the topological parameters shown in Table 7 were also used to describe the nature of the $\mathrm{Cd}-\mathrm{N}, \mathrm{Cd}-\mathrm{O}$, and $\mathrm{Cd}-\mathrm{Cl}$ metal-ligand interactions. The interaction energies calculated using the Espinosa relationship [65] showed very good correlation with the $\mathrm{Cd}-\mathrm{N}$ distances (Figure 11). The interaction energies dramatically decreased with the increase in $\mathrm{Cd}-\mathrm{N}$ distances, which agrees with previous studies [17-19]. On other hand, the total electron density $\rho(\mathrm{r})$ values are less than 0.1 a.u., indicating predominant closed-shell interactions for the $\mathrm{Cd}-\mathrm{N}, \mathrm{Cd}-\mathrm{O}$, and $\mathrm{Cd}-\mathrm{Cl}$ coordinate bonds, where shorter bonds have higher $\rho(\mathrm{r})$ values than longer ones. On other hand, the results showed that shorter $\mathrm{Cd}-\mathrm{N}$ interactions have negative total energy density $\mathrm{H}(\mathrm{r})$ and $\mathrm{V}(\mathrm{r}) / \mathrm{G}(\mathrm{r})$ ratios slightly more than one, indicating some covalent characteristics for these interactions, while the opposite is true for longer $\mathrm{Cd}-\mathrm{N}$ bonds which mainly belong to closed-shell interactions with negligible covalent characteristics (Figure 12). It is clear that a cut-off of about $2.4 \AA$ for the $\mathrm{Cd}-\mathrm{N}$ distances could be considered as a border between the closed-shell interactions and those having significant covalent characteristics. The results also showed that $\mathrm{Cd}-\mathrm{Cl}$ and $\mathrm{Cd}-\mathrm{O}$ coordinate bonds have the main characteristics of closed-shell interactions with positive $\mathrm{H}(\mathrm{r})$ and $\mathrm{V}(\mathrm{r}) / \mathrm{G}(\mathrm{r})$ ratios $<1$.

Table 7. The atoms in molecules (AIM) topology parameters (a.u.) of the $\mathrm{Cd}-\mathrm{N}, \mathrm{Cd}-\mathrm{Cl}$, and $\mathrm{Cd}-\mathrm{O}$ interactions of complexes 1 and 2.

\begin{tabular}{lcccccc}
\hline & $\boldsymbol{\rho}(\mathbf{r})$ & $\mathbf{G}(\mathbf{r})^{\mathbf{a}}$ & $\mathbf{V}(\mathbf{r})^{\mathbf{a}}$ & $\mathbf{H}(\mathbf{r})$ & $\mathbf{V}(\mathbf{r}) / \mathbf{G}(\mathbf{r})$ & E $_{\text {int }}$ kcal/mol \\
\hline & & & Complex $\mathbf{r}$ & & & \\
Cd1-N1 & 0.0361 & 0.0549 & -0.0553 & -0.0005 & 1.0085 & 17.36 \\
Cd1-N2 & 0.0446 & 0.0691 & -0.0729 & -0.0038 & 1.0551 & 22.88 \\
Cd1-N3 & 0.0294 & 0.0600 & -0.0616 & -0.0016 & 1.0262 & 19.32 \\
& & & Complex 2 & & & \\
Cd1-C11 & 0.0270 & 0.0427 & -0.0405 & 0.0021 & 0.9499 & 12.71 \\
Cd2-Cl1 & 0.0285 & 0.0430 & -0.0414 & 0.0015 & 0.9648 & 13.00 \\
Cd1-O1 & 0.0351 & 0.0615 & -0.0606 & 0.0009 & 0.9847 & 19.00 \\
Cd2-O2 & 0.0368 & 0.0618 & -0.0616 & 0.0001 & 0.9978 & 19.34 \\
Cd1-N1 & 0.0386 & 0.0599 & -0.0612 & -0.0013 & 1.0219 & 19.19 \\
Cd1-N2 & 0.0316 & 0.0496 & -0.0483 & 0.0013 & 0.9729 & 15.15 \\
Cd1-N4 & 0.0386 & 0.0609 & -0.0623 & -0.0015 & 1.0244 & 19.56 \\
Cd1-N8 & 0.0319 & 0.0503 & -0.0490 & 0.0013 & 0.9737 & 15.37 \\
Cd1-N9 & 0.0336 & 0.0513 & -0.0509 & 0.0004 & 0.9929 & 15.98 \\
Cd2-N10 & 0.0318 & 0.0471 & -0.0463 & 0.0008 & 0.9840 & 14.53 \\
Cd2-N11 & 0.0331 & 0.0512 & -0.0503 & 0.0009 & 0.9826 & 15.79 \\
Cd2-N13 & 0.0380 & 0.0583 & -0.0597 & -0.0014 & 1.0246 & 18.73 \\
Cd2-N17 & 0.0314 & 0.0482 & -0.0468 & 0.0014 & 0.9713 & 14.68 \\
Cd2-N18 & 0.0371 & 0.0561 & -0.0568 & -0.0007 & 1.0133 & 17.83 \\
\hline
\end{tabular}

${ }^{a} \mathrm{~V}(\mathrm{r})$ and $\mathrm{G}(\mathrm{r})$ are the potential and kinetic energy density, respectively. 


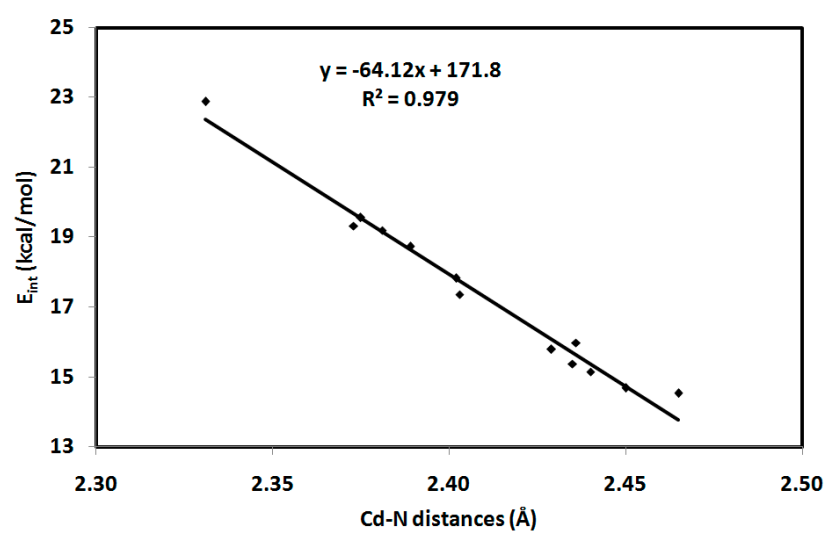

Figure 11. Inverse correlation between the interaction energy $\left(\mathrm{E}_{\mathrm{int}}\right)$ and $\mathrm{Cd}-\mathrm{N}$ distance of complexes 1 and 2.

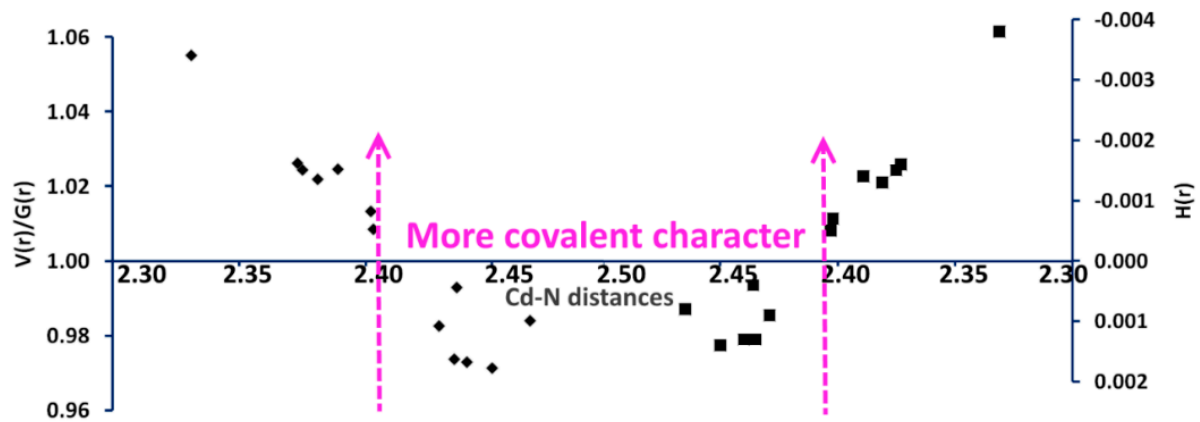

Figure 12. Relationship between the $H(r)$ and $V(r) / G(r)$ ratio and the $C d-N$ distances $(\AA)$ in complexes 1 and 2.

\subsection{Comparative Study}

In our previous studies [17-19,66-68], we reported detailed structural studies on the Mn(II), $\mathrm{Cd}(\mathrm{II})$, and Ni(II) complexes of the neutral ligands BDMPT and MBPT. Here, we present a comparative discussion on the affinity of these ligands toward some divalent metal ions based on the reported $X$-ray structures of their well-known complexes and those presented here in this publication. For this task, we calculated the interaction energies of the $[\mathrm{M}-\mathrm{L}]^{2+}$ complex cation units of these systems. The results are listed in Table 8. There is no doubt that such sterically hindered cavity-containing ligands have higher affinity to large metal ions such as $\mathrm{Cd}(\mathrm{II})$. It is clear that the $\mathrm{Cd}(\mathrm{II})-\mathrm{L}$ interaction energies of $[\mathrm{Cd}(\mathrm{BDMPT})]^{2+}$ and $[\mathrm{Cd}(\mathrm{MBPT})]^{2+}$ are at least four times higher than the corresponding $\mathrm{Mn}$ (II) and Ni(II) complexes. It is so obvious that the large size M(II) could fit better in the ligand cavity and strongly bond to the N-atoms of BDMPT or MBPT ligands without suffering from high steric hinderance between the two ligand arms. In contrast, the presence of such bulky groups around the $s$-triazine core prevents these moieties from approaching each other to a certain limit, which explains the weaker interactions with the smaller M(II) ions such as $\mathrm{Mn}$ (II) and $\mathrm{Ni}(\mathrm{II})$. Another factor which slightly affects the interaction energies; it is the presence of a coordinating anion inside the coordination sphere. The presence of an anion directly coordinating to the M(II) ion weakens the interaction with the s-triazine ligand as a result of the compensation of the divalent metal ion positive charge by the negative charge from the anionic ligand. 
Table 8. The calculated interaction energies of the $[\mathrm{M}(\mathrm{II})-\mathrm{L}]^{2+}$ units.

\begin{tabular}{ccccc}
\hline Complex & {$[\mathbf{M}(\mathbf{I I})-\mathbf{L}]^{\mathbf{2 +}}$} & $\mathbf{L}^{\mathbf{a}}$ & $\mathbf{M}(\mathbf{I I})^{\mathbf{b}}$ & $\mathbf{E}_{\text {int }}{ }^{\mathbf{d}}$ \\
\hline$\left[\mathrm{Mn}(\mathrm{BDMPT})\left(\mathrm{H}_{2} \mathrm{O}\right)_{2} \mathrm{Cl}\right] \mathrm{Cl}$ & -2152.5313 & -1001.9710 & -1150.1470 & -259.3372 \\
{$\left[\mathrm{Mn}(\mathrm{BDMPT})\left(\mathrm{H}_{2} \mathrm{O}\right)_{3}\right]\left(\mathrm{ClO}_{4}\right)_{2} \cdot \mathrm{H}_{2} \mathrm{O}$} & -2152.5388 & -1001.9684 & -1150.1470 & -265.6799 \\
{$\left[\mathrm{Mn}(\mathrm{BDMPT})_{2}\right]\left(\mathrm{ClO}_{4}\right)_{2}$} & -2152.5342 & -1001.9643 & -1150.1470 & $-266.5690^{\mathrm{c}}$ \\
{$\left[\mathrm{Mn}(\mathrm{BDMPT})\left(\mathrm{H}_{2} \mathrm{O}\right)_{3}\right]\left(\mathrm{NO}_{3}\right)_{2} \cdot \mathrm{H}_{2} \mathrm{O}$} & -2152.5323 & -1001.9701 & -1150.1470 & -260.5259 \\
{$\left[\mathrm{Ni}(\mathrm{BDMPT})\left(\mathrm{H}_{2} \mathrm{O}_{2} \mathrm{Cl}\right] \mathrm{Cl}\right.$} & -2509.8376 & -1001.9610 & -1507.3050 & -358.6813 \\
{$\left[\mathrm{Cd}(\mathrm{BDMPT}) \mathrm{Cl}_{2}\right]$} & -2761.6162 & -1001.9707 & -1757.4389 & -1384.6861 \\
{$\left[\mathrm{Cd}(\mathrm{BDMPT})\left(\mathrm{NO}_{3}\right)_{2}\left(\mathrm{H}_{2} \mathrm{O}\right)\right]$} & -2761.6101 & -1001.9714 & -1757.4389 & -1380.3829 \\
$\mathbf{1}$ & -2761.7279 & -1001.9656 & -1757.4389 & $-1457.9655^{\mathrm{c}}$ \\
{$\left[\mathrm{Mn}(\mathrm{MBPT})(\mathrm{MeOH}) \mathrm{NO}_{3}\right] \mathrm{NO}_{3} \cdot \mathrm{MeOH}$} & -2337.0686 & -1186.4005 & -1150.1470 & -326.9324 \\
{$\left[\mathrm{Mn}(\mathrm{MBPT})\left(\mathrm{H}_{2} \mathrm{O}_{2}\right]\left(\mathrm{NO}_{3}\right)_{2}\right.$} & -2337.0039 & -1186.3295 & -1150.1470 & $-329.0932^{\mathrm{c}}$ \\
{$\left[\mathrm{Cd}(\mathrm{MBPT}) \mathrm{Cl}_{2}\right] \mathrm{H}_{2} \mathrm{O}^{*} 1 / 2 \mathrm{MeOH} \mathrm{MeO}$} & -2946.9519 & -1186.2843 & -1757.4389 & $-2026.0395^{\mathrm{c}}$ \\
{$\left[\mathrm{Cd}(\mathrm{MBPT})\left(\mathrm{NO}_{3}\right)\left(\mathrm{MeOH}^{\mathrm{c}}\right] \mathrm{NO}_{3} \mathrm{MeOH}\right.$} & -2947.1183 & -1186.3260 & -1757.4389 & -2104.2816 \\
$\mathbf{2}$ & -2947.2042 & -1186.3329 & -1757.4389 & $-2161.3672^{\mathrm{c}}$ \\
\hline
\end{tabular}

${ }^{\mathrm{a}} \mathrm{L}=\mathrm{BDMPT}$ or MBPT; ${ }^{\mathrm{b}} \mathrm{M}(\mathrm{II})=\mathrm{Cd}(\mathrm{II}), \mathrm{Mn}(\mathrm{II}), \mathrm{Ni}(\mathrm{II}){ }^{\mathrm{c}}{ }^{\mathrm{average}}$ value; ${ }^{\mathrm{d}} \mathrm{E}_{\text {int }}=\mathrm{E}_{\text {complex }}-\left(\mathrm{E}_{\text {metal }}+\mathrm{E}_{\text {ligand }}\right)$.

\section{Conclusions}

The homoleptic $\left[\mathrm{Cd}(\mathrm{BDMPT})_{2}\right]\left(\mathrm{ClO}_{4}\right)_{2}(\mathbf{1})$ and heteroleptic $\left[\mathrm{Cd}_{2}(\mathrm{MBPT})_{2}\left(\mathrm{H}_{2} \mathrm{O}\right)_{2} \mathrm{Cl}\right]\left(\mathrm{ClO}_{4}\right)_{3} \cdot 4 \mathrm{H}_{2} \mathrm{O}$ (2) s-triazine pincer-type complexes were synthesized and characterized using FTIR, NMR, and single-crystal X-ray diffraction techniques. In $\mathbf{1}$, the $\mathrm{Cd}(\mathrm{II})$ is hexa-coordinated with two tridentate $\mathrm{N}$-chelates and the coordination geometry is significantly distorted compared to the octahedral and trigonal prism configurations. In 2 , the two Cd(II) are hepta-coordinated with distorted pentagonal bipyramidal coordination geometry. The molecular packing in both complexes was analyzed using Hirshfeld analysis. Complex 1 thermally decomposed at higher temperature $\left(273^{\circ} \mathrm{C}\right)$ compared to the free ligand BDMPT $\left(185^{\circ} \mathrm{C}\right)$. On other hand, the coordinated organic ligand of 2 decomposed at $273{ }^{\circ} \mathrm{C}$ after losing the crystal and coordinated water molecules, while the free ligand MBPT decomposed at $235^{\circ} \mathrm{C}$. Using atoms in molecules, the shorter $\mathrm{Cd}-\mathrm{N}$ coordinate bonds have higher covalent characteristics than the longer ones. The interaction energies of the BDMPT or MBPT ligands with metal ions having larger size are higher than those for smaller-size metal ions, in agreement with the steric preference of these ligands.

Supplementary Materials: The following are available online at http://www.mdpi.com/2073-4352/9/5/226/s1. Figure S1: FTIR spectra of complexes $\mathbf{1}$ and 2. Figure S2: ${ }^{1} \mathrm{H}$ and ${ }^{13} \mathrm{C}$ NMR spectra of complex $\mathbf{1}$. Figure S3: ${ }^{1} \mathrm{H}$ and ${ }^{13} \mathrm{C}$ NMR spectra of complex 2. Figure S4: Hirshfeld surfaces of the studied complexes.

Author Contributions: The preparations of the organic ligands were carried out by Z.A.M. and A.E.F. Also, they performed the elemental analysis, TGA, and NMR analyses; FTIR and X-ray analyses, together with the computational calculations, as well as the synthesis of complexes $\mathbf{1}$ and 2, were carried out by S.M.S. All authors contributed in the preparation of the first and final versions of the manuscript.

Funding: The Deanship of Scientific Research at King Saud University, Saudi Arabia funded this research.

Acknowledgments: The authors extend their appreciation to the Deanship of Scientific Research at King Saud University for funding this work through research group No. RGP-234 (Saudi Arabia).

Conflicts of Interest: The authors declare no conflicts of interest.

\section{References}

1. Stang, P.J.; Olenyuk, B. Self-Assembly, Symmetry, and Molecular Architecture: Coordination as the Motif in the Rational Design of Supramolecular Metallacyclic Polygons and Polyhedra. Acc. Chem. Res. 1997, 30, 502-518. [CrossRef]

2. Braga, D.; Grepioni, F.; Desiraju, G.R. Crystal Engineering and Organometallic Architecture. Chem. Rev. 1998, 98, 1375-1406. [CrossRef] [PubMed]

3. Yaghi, O.M.; Li, H.; Davis, C.; Richardson, D.; Groy, T.L. Synthetic Strategies, Structure Patterns, and Emerging Properties in the Chemistry of Modular Porous Solids. Acc. Chem. Res. 1998, 31, 474-484. [CrossRef] 
4. Purdy, A.P.; Gilardi, R.; Luther, J.; Butcher, R.J. Synthesis, crystal structure, and reactivity of alkali and silver salts of sulfonated imidazoles. Polyhedron 2007, 26, 3930-3938. [CrossRef]

5. Zhang, Z.-T.; Shi, J.; He, Y.; Guo, Y.-N. Self-assembly and crystal structure of a barium sulfonatechrysin coordination polymer. Inorg. Chem. Commun. 2006, 9, 579-581. [CrossRef]

6. Yang, X.-L.; Ren, S.-B.; Zhang, J.; Li, Y.-Z.; Du, H.-B.; You, X.-Z. Syntheses and structures of three coordination polymers based on 4-methylbenzenethiolates of $\mathrm{Zn}(\mathrm{II})$ and $\mathrm{Cd}(\mathrm{II})$ and bipyridine. J. Coord. Chem. 2009, 62, 3782-3794. [CrossRef]

7. Ghoshal, D.; Maji, T.K.; Mostafa, G.; Lu, T.H.; Chaudhuri, N.R. A Three-dimensional honeycomb-Like network constructed with novel "Sinusoidal" One-Dimensional Chains via Hydrogen Bonding and $\pi-\pi$ Interactions. Cryst. Growth Des. 2003, 3, 9-11. [CrossRef]

8. Rashidi-Ranjbar, Z.; Hamidi, S.; Heshmatpour, F.; Morsali, A. Thermal, spectroscopic, X-ray powder diffraction, and structural studies on a new Cd(II) mixed-ligand coordination polymer. J. Coord. Chem. 2009, 62, 2022-2027. [CrossRef]

9. Smith, G.; Wermuth, U.D.; Young, D.J.; White, J.M. Polymeric structures in the metal complexes of 5-sulfosalicylic acid: The rubidium(I), caesium(I) and lead(II) analogues. Polyhedron 2007, 26, 3645-3652. [CrossRef]

10. Wang, C.-J.; Ren, P.-D.; Zhang, Z.-B.; Fang, Y.; Wang, Y.-Y. Synthesis and characterization of a nickel-organic framework encapsulating hetero-chiral helical water chains in the 1-D channels. J. Coord. Chem. 2009, 62, 2814-2823. [CrossRef]

11. De Silva, C.-R.; Maeyer, J.-R.; Dawson, A.; Zheng, Z. Adducts of lanthanide $\beta$-diketonates with 2,4,6-tri(2-pyridyl)-1,3,5-triazine: Synthesis, structural characterization, and photoluminescence studies. Polyhedron 2007, 26, 1229-1238. [CrossRef]

12. Ionova, G.; Raber, C.; Guillaumont, R.; Ionov, S.; Madic, C.; Krupa, D.; Guillaneux, J.-C. A donor-acceptor model of Ln(III) complexation with terdentate nitrogen planar ligands. New J. Chem. 2002, 26, 234-242. [CrossRef]

13. Yan, C.; Chen, Q.; Chen, L.; Feng, R.; Shan, X.; Jiang, F.; Hong, M. crystal structures and luminescence behaviour of $\mathrm{d}^{10}$ Metal-Organic Complexes with multipyridine ligands. Aust. J. Chem. 2011, 64, 104-118. [CrossRef]

14. Wu, G.; Wang, X.-F.; Guo, L.; Li, H.-H. Zn(II) and Cd(II) Complexes extended structures sustained by hydrogen bonding, $\pi-\pi$ and $C-H \cdots \pi$ interactions. J. Chem. Crystallogr. 2011, 41, 1071-1076. [CrossRef]

15. Glaser, T.; Lügger, T.; Fröhlich, R. Synthesis, crystal structures, and magnetic properties of a mono- and a dinuclearcopper(II) complex of the 2,4,6-tris(2-pyridyl)-1,3,5-triazine ligand. Eur. J. Inorg. Chem. 2004, 2004, 394-400. [CrossRef]

16. Schwalbe, M.; Karnahl, M.; Görls, H.; Chartrand, D.; Laverdiere, F.; Hanan, G.-S.; Tschierlei, S.; Dietzek, B.; Schmitt, M.; Popp, J.; et al. Ruthenium polypyridine complexes of tris-(2-pyridyl)-1,3,5-triazine-Unusual building blocks for the synthesis of photochemical molecular devices. Dalton Trans. 2009, 4012-4022. [CrossRef] [PubMed]

17. Soliman, S.M.; El-Faham, A. Synthesis, characterization, and structural studies of two heteroleptic Mn(II) complexes with tridentate N,N,N-pincer type ligand. J. Coord. Chem. 2018, 71, 2373-2388. [CrossRef]

18. Soliman, S.M.; El-Faham, A. One pot synthesis of two Mn(II) perchlorate complexes with s-triazine NNN-pincer ligand; molecular structure, Hirshfeld analysis and DFT studies. J. Mol. Struct. 2018, 1164, 344-353. [CrossRef]

19. Soliman, S.M.; El-Faham, A.; Elsilk, S.E.; Farooq, M. Two heptacoordinated manganese(II) complexes of giant pentadentate s-triazinebis-Schiff base ligand: Synthesis, crystal structure, biological and DFT studies. Inorg. Chim. Acta 2018, 479, 275-285. [CrossRef]

20. Nawrot, I.; Machura, B.; Kruszynski, R. Thiocyanate cadmium(II) complexes of 2,4,6-tri(2-pyridyl)-1,3,5triazine-Synthesis, structure and luminescence properties. J. Luminescence 2014, 156, 240-254. [CrossRef]

21. Zhao, X.X.; Qin, Z.B.; Li, Y.H.; Cui, G.H. New Cd(II) and Zn(II) coordination polymers showing luminescent sensing for $\mathrm{Fe}(\mathrm{III})$ and photocatalytic degrading methylene blue. Polyhedron 2018, 153, 197-204. [CrossRef]

22. Cheng, H.J.; Lu, Y.F.; Li, C.; Shu, Y.; Ma, J.; Li, W.H.; Yuan, R.X. Two Cd(II) coordination polymers based on 3,6-bis(imidazol-1-yl)carbazole: Syntheses, structures and photocatalytic properties. Inorg. Chem. Commun. 2016, 73, 12-15. [CrossRef] 
23. Gong, W.J.; Yao, R.; Li, H.X.; Ren, Z.G.; Zhang, J.G.; Lang, J.P. Luminescent cadmium(II) coordination polymers of 1,2,4,5-tetrakis(4-pyridylvinyl)benzene used as efficient multi-responsive sensors for toxic metal ions in water. Dalton Trans. 2017, 46, 16861-16871. [CrossRef] [PubMed]

24. Wang, Q.; Wang, S.; Feng, X.; Wu, L.; Zhang, G.; Zhou, M.; Wang, B.; Yang, L. A Heat-Resistant and Energetic Metal-Organic Framework Assembled by Chelating Ligand. ACS Appl. Mater. Interfaces 2017, 9, 37542-37547. [CrossRef] [PubMed]

25. Liu, X.; Gao, W.; Sun, P.; Su, Z.; Chen, S.; Wei, Q.; Xie, G.; Gao, S. Environmentally friendly high-energy MOFs: crystal structures, thermos stability, insensitivity and remarkable detonation performances. Green Chem. 2015, 17, 831-836. [CrossRef]

26. Feng, Y.; Liu, X.; Duan, L.; Yang, Q.; Wei, Q.; Xie, G.; Chen, S.; Yang, X.; Gao, S. In situ synthesized 3D heterometallic metal-organic framework (MOF) as a high-energy-density material shows high heat of detonation, good thermo stability and insensitivity. Dalton Trans. 2015, 4, 2333-2339. [CrossRef]

27. Wang, S.; Wang, Q.; Feng, X.; Wang, B.; Yang, L. Explosives in the Cage: Metal-Organic Frameworks for high-energy materials sensing and desensitization. Adv. Mater. 2017, 29, 1701898. [CrossRef] [PubMed]

28. Zhang, Q.; Shreeve, J.M. Metal-organic frameworks as high explosives: a new concept for energetic materials. Angew. Chem. Int. Ed. 2014, 53, 2540-2542. [CrossRef]

29. Bushuyev, O.S.; Brown, P.; Maiti, A.; Gee, R.H.; Peterson, G.R.; Weeks, B.L.; Hope-Weeks, L.J. Ionic Polymers as a New Structural Motif for High-Energy-Density Materials. J. Am. Chem. Soc. 2012, 134, 1422-1425. [CrossRef]

30. Bushuyev, O.S.; Peterson, G.R.; Brown, P.; Maiti, A.; Gee, R.H.; Weeks, B.L.; Hope-Weeks, L.J. Metal-organic frameworks (MOFs) as safer, structurally reinforced energetic. Chem. Eur. J. 2013, 19, 1706-1711. [CrossRef]

31. Li, S.; Wang, Y.; Qi, C.; Zhao, X.; Zhang, J.; Zhang, S.; Pang, S. 3D Energetic Metal-Organic Frameworks: Synthesis and Properties of High Energy Materials. Angew. Chem. Int. Ed. 2013, 52, 14031-14035. [CrossRef]

32. Zhang, S.; Yang, Q.; Liu, X.; Qu, X.; Wei, Q.; Xie, G.; Chen, S.; Gao, S. High-energy metal-organic frameworks (HE-MOFs): Synthesis, structure and energetic performance. Coord. Chem. Rev. 2016, 307, $292-312$. [CrossRef]

33. McDonald, K.A.; Seth, S.; Matzger, A.J. Coordination Polymers with High Energy Density: An Emerging Class of Explosives. Cryst. Growth Des. 2015, 1, 5963-5972. [CrossRef]

34. Blair, L.H.; Colakel, A.; Vrcelj, R.M.; Sinclair, I.; Coles, S.J. Metal-organic fireworks: MOFs as integrated structural scaffolds for pyrotechnic materials. Chem. Commun. 2015, 5, 12185-12188. [CrossRef]

35. Zhang, J.; Du, Y.; Dong, K.; Su, H.; Zhang, S.; Li, S.; Pang, S. Taming Dinitramide Anions within an Energetic Metal-Organic Framework: A New Strategy for Synthesis and Tunable Properties of High Energy Materials. Chem. Mater. 2016, 28, 1472-1480. [CrossRef]

36. Yang, L.L.; Tan, X.X.; Wang, Z.Q.; Zhang, X. Supramolecular Polymers: Historical Development, Preparation, Characterization, and Functions. Chem. Rev. 2015, 115, 7196-7239. [CrossRef]

37. Li, Z.X.; Zhang, X.; Liu, Y.C.; Zou, K.Y.; Yue, M.L. Controlling the BET Surface Area of Porous Carbon by Using the $\mathrm{Cd} / \mathrm{C}$ Ratio of a Cd-MOF Precursor and Enhancing the Capacitance by Activation with $\mathrm{KOH}$. Chem. Eur. J. 2016, 22, 17734-17747. [CrossRef]

38. Sheldrick, G.M.; SADABS. Program for Empirical Absorption Correction of Area Detector Data; University of Göttingen: Göttingen, Germany, 1996.

39. Dolomanov, O.V.; Bourhis, L.J.; Gildea, R.J.; Howard, J.A.K.; Puschmann, H. OLEX2: A complete structure solution, refinement and analysis program. J. Appl. Cryst. 2009, 42, 339-341. [CrossRef]

40. Sheldrick, G.M. A Short History of SHELX. Acta Cryst. A 2008, 64, 112-122. [CrossRef]

41. Sheldrick, G.M. SHELXT_-Integrated space-group and crystal-structure determination. Acta Cryst. A 2015, 71,3-8. [CrossRef]

42. Spek, A.L. Structure validation in chemical crystallography. Acta Cryst. 2009, D65, 148-155. [CrossRef] [PubMed]

43. Hirshfeld, F.L. Bonded-atom fragments for describing molecular charge densities. Theor. Chim. Acta 1977, 44, 129-138. [CrossRef]

44. Spackman, M.A.; Jayatilaka, D. Hirshfeld surface analysis. CrystEngComm 2009, 11, 19-32. [CrossRef]

45. Spackman, M.A.; McKinnon, J.J. Fingerprinting intermolecular interactions in molecular crystals. CrystEngCommun 2002, 4, 378-392. [CrossRef] 
46. Bernstein, J.; Davis, R.E.; Shimoni, L.; Chang, N.-L. Patterns in hydrogen bonding: Functionality and graph set analysis in crystals. Angew. Chem. Int. Ed. 1995, 34, 1555-1573. [CrossRef]

47. McKinnon, J.J.; Jayatilaka, D.; Spackman, M.A. Towards quantitative analysis of intermolecular interactions with Hirshfeldsurfaces. Chem. Commun. 2007, 3814-3816. [CrossRef]

48. Crystal Explorer 17. 2017. Available online: http://hirshfeldsurface.net (accessed on 27 April 2019).

49. Frisch, M.J.; Trucks, G.W.; Schlegel, H.B.; Scuseria, G.E.; Robb, M.A.; Cheeseman, J.R.; Scalmani, G.; Barone, V.; Mennucci, B.; Petersson, G.A.; et al. GAUSSIAN 09. Revision A02; Gaussian Inc.: Wallingford, CT, USA, 2009.

50. Chai, J.D.; Head-Gordon, M. Long-range corrected hybrid density functionals with damped atom-atom dispersion corrections. Phys. Chem. Chem. Phys. 2008, 10, 6615-6620. [CrossRef] [PubMed]

51. Glendening, E.D.; Reed, A.E.; Carpenter, J.E.; Weinhold, F. NBO Version 3.1, CI; University of Wisconsin: Madison, WI, USA, 1998.

52. Lu, T.; Chen, F. Multiwfn: A multifunctional wave function analyzer. J. Comput. Chem. 2012, 33, 580-592. [CrossRef]

53. Ok, K.M.; Halasyamani, P.S.; Casanova, D.; Llunell, M.; Alvarez, S. Distortions in octahedrally coordinated d0 transition metal oxides: A continuous symmetry measures approach. Chem. Mater. 2006, 18, 3176-3183. [CrossRef]

54. Santiaqo, A.; David, A.; Llunell, M.; Pinsky, M. Continuous symmetry maps and shape classification. The case of six-coordinated metal compounds. New J. Chem. 2002, 26, 996-1009.

55. Hagit, Z.; Shmuel, P.; David, A. Continuous symmetry measures. J. Am. Chem. Soc. 1992, 114, 7843-7851.

56. Keinan, S.; Avnir, D. Quantitative Symmetry in Structure-Activity Correlations: The Near C2Symmetry of Inhibitor/HIV Protease Complexes. J. Am. Chem. Soc. 2000, 122, 4378-4384. [CrossRef]

57. Bader, R.F.W. Atoms in Molecules: A Quantum Theory; Oxford University Press: Oxford, UK, 1990.

58. Matta, C.F.; Hernandez-Trujillo, J.; Tang, T.-H.; Bader, R.F.W. Hydrogen-hydrogen bonding: A stabilizing interaction in molecules and crystals. Chem. Eur. J. 2003, 9, 1940-1951. [CrossRef]

59. Grabowski, S.J.; Pfitzner, A.; Zabel, M.; Dubis, A.T.; Palusiak, M. Intramolecular H ... H interactions for the Crystal Structures of [4-((E)-But-1-enyl)-2,6-dimethoxyphenyl]pyridine-3-carboxylate and [4-((E)-Pent-1-enyl)-2,6-dimethoxyphenyl]pyridine-3-carboxylate; DFT calculations on modeled styrene derivatives. J. Phys. Chem. B 2004, 108, 1831-1837. [CrossRef]

60. Matta, C.F.; Castillo, N.; Boyd, R.J. Characterization of a closed-shell fluorine-fluorine bonding interaction in aromatic compounds on the basis of the electron density. J. Phys. Chem. A 2005, 109, 3669-3681. [CrossRef]

61. Pendás, A.M.; Francisco, E.; Blanco, M.A.; Gatti, C. Bond paths as privileged exchange channels. Chem. Eur. J. 2007, 13, 9362-9371.

62. Bobrov, M.F.; Popova, G.V.; Tsirelson, V.G. A topological analysis of electron density and chemical bonding in cyclophosphazenes $\mathrm{P}_{\mathrm{n}} \mathrm{N}_{\mathrm{n}} \mathrm{X}_{2 \mathrm{n}}(\mathrm{X}=\mathrm{H}, \mathrm{F}, \mathrm{Cl} ; \mathrm{n}=2,3,4)$. Russ. J. Phys. Chem. 2006, 80, 584-590. [CrossRef]

63. Gatti, C. Chemical bonding in crystals: New directions. Z. Kristallogr. 2005, 220, 399-457. [CrossRef]

64. Gibbs, G.V.; Downs, R.T.; Cox, D.F.; Ross, N.L.; Boisen, M.B., Jr.; Rosso, K.M. Shared and closed-shell O-O interactions in silicates. J. Phys. Chem. A 2008, 112, 3693-3699. [CrossRef]

65. Espinosa, E.; Molins, E.; Lecomte, C. Hydrogen bond strengths revealed by topological analyses of experimentally observed electron densities. Chem. Phys. Lett. 1998, 285, 170-173. [CrossRef]

66. Soliman, S.M.; El-Faham, A.; Elsilk, S.E.; Farooq, M. Synthesis and structure diversity of high coordination number Cd(II) complexes of large s-triazinebis-Schiff base pincer chelate. Inorg. Chim. Acta 2019, 488, 131-140. [CrossRef]

67. Soliman, S.M.; El-Faham, A. Synthesis, molecular structure and DFT studies of two heteroleptic nickel(II) s-triazine pincer type complexes. J. Mol. Struct. 2019, 1185, 461-468. [CrossRef]

68. Soliman, S.M.; El-Faham, A. Synthesis, X-ray structure and DFT studies of penta- and octa-coordinated Cd(II) complexes with s-triazineN-pincer chelate. J. Coord. Chem. 2019, in press. [CrossRef]

(C) 2019 by the authors. Licensee MDPI, Basel, Switzerland. This article is an open access article distributed under the terms and conditions of the Creative Commons Attribution (CC BY) license (http://creativecommons.org/licenses/by/4.0/). 